\title{
molecules
}

ISSN 1420-3049

Full Paper

http://www.mdpi.org

\section{Proteasome and NF- $\kappa$ B Inhibiting Phaeophytins from the Green Alga Cladophora fascicularis}

\author{
Xinping Huang ${ }^{1,2}$, Min Li ${ }^{1, *}$, Bo Xu ${ }^{1}$, Xiaobin Zhu ${ }^{2}$, Zhiwei Deng ${ }^{3}$ and Wenhan Lin ${ }^{1, *}$ \\ ${ }^{1}$ State Key Laboratory of Natural and Biomimetic Drugs, Peking University, Beijing 100083, P.R. \\ China, Tel: (+86) 10-82806188; Fax: (+86) 10-82802724 \\ ${ }^{2}$ Institute of Oceanology, Chinese Academy of Sciences, Qingdao 266071, P.R. China \\ ${ }^{3}$ Analytic and Testing Center, Beijing Normal University, Beijing 100073, P.R. China \\ * Authors to whom correspondence may be addressed; E-mails: limin@bjmu.edu.cn; \\ whlin@bjmu.edu.cn
}

Received: 18 February 2007; in revised form: 18 March 2007 / Accepted: 21 March 2007 / Published: 21 March 2007

\begin{abstract}
Chemical examination of the green alga Cladophora fascicularis resulted in the isolation and characterization of a new porphyrin derivative, porphyrinolactone (1), along with five known phaeophytins 2-6 and fourteen sterols and cycloartanes. The structure of $\mathbf{1}$ was determined on the basis of spectroscopic analyses and by comparison of its NMR data with those of known phaeophytins. Compounds 1-6 displayed moderate inhibition of tumor necrosis factor alpha (TNF- $\alpha$ ) induced nuclear factor- $\kappa \mathrm{B}$ (NF- $\kappa \mathrm{B}$ ) activation, while $\mathbf{2}$ and $\mathbf{4}$ displayed potential inhibitory activity toward proteasome chymotripsin-like activation. The primary structure-activity relationship was also discussed.
\end{abstract}

Keywords: Green alga, Cladophora fascicularis, porphyrinolactone, NF- $\kappa \mathrm{B}$, proteasome

\section{Introduction}

The genus Cladophora (Cladophoraceae) is a group of filamentous green algae that grows widely in eutrophic wastewater and marine intertidal zones. Previous chemical investigations indicated that 
Cladophora mainly containing sterol derivatives [1-3]. Terpenes [4] from C. vagabunda in Black Sea and a brominated diphenyl ether from C. fascicularis [5] were also reported. In the course of our investigation of chemical diversity and the bioactive compounds from marine plants, the green alga $C$. fascicularis was collected from shallow seawater along the coastline of Qingdao, China. The EtOH extract showed moderate cytotoxicity against human tumor cell lines, including Hela and LH-1210 (inhibition rates of $92 \%$ and $85 \%$ per $20 \mu \mathrm{g} / \mathrm{mL}$, respectively). Chromatography of this extract resulted in the isolation of six phaeophytin derivatives 1-6, along with eight steroids and six cycloartanes. In this paper, we report the structural elucidation of the new phaeophytin derivative porphyrinolactone (1), and the inhibitory effects of compounds 1-6 against proteasome chymotripsin-like and TNF- $\alpha$-induced $\mathrm{NF}-\kappa \mathrm{B}$ activation.

\section{Results and Discussion}

Extensive chromatography of EtOH extract of marine alga $C$. fascicularis resulted in the isolation and characterization of six phaeophytins 1-6 (Figure 1), along with fourteen known steroids and cycoartanes. Porphyrinolactone (1) was determined as a new paeophytin derivative, while $\mathbf{2}$ to $\mathbf{6}$ were identified as 20-chlorinated (132-S)-hydroxyphaeophytin A (2), $\left(13^{2}-S\right)$-hydroxyphaeophytin B (3) and A (5), and $\left(13^{2}-R\right)$-hydroxyphaeophytin B (4) and A (6) through spectroscopic analyses and by comparison of their NMR data with literature values [6-7]. Compound 2 was isolated from Nature for the first time, and its incomplete NMR data [8] was fully assigned through extensive 2D NMR spectroscopic analyses. Compounds 3-6 were previously isolated from liverwort and hornwort and reported to possess cytostatic and antibacterial activities [9].

Figure 1. Structures of compounds 1-6.
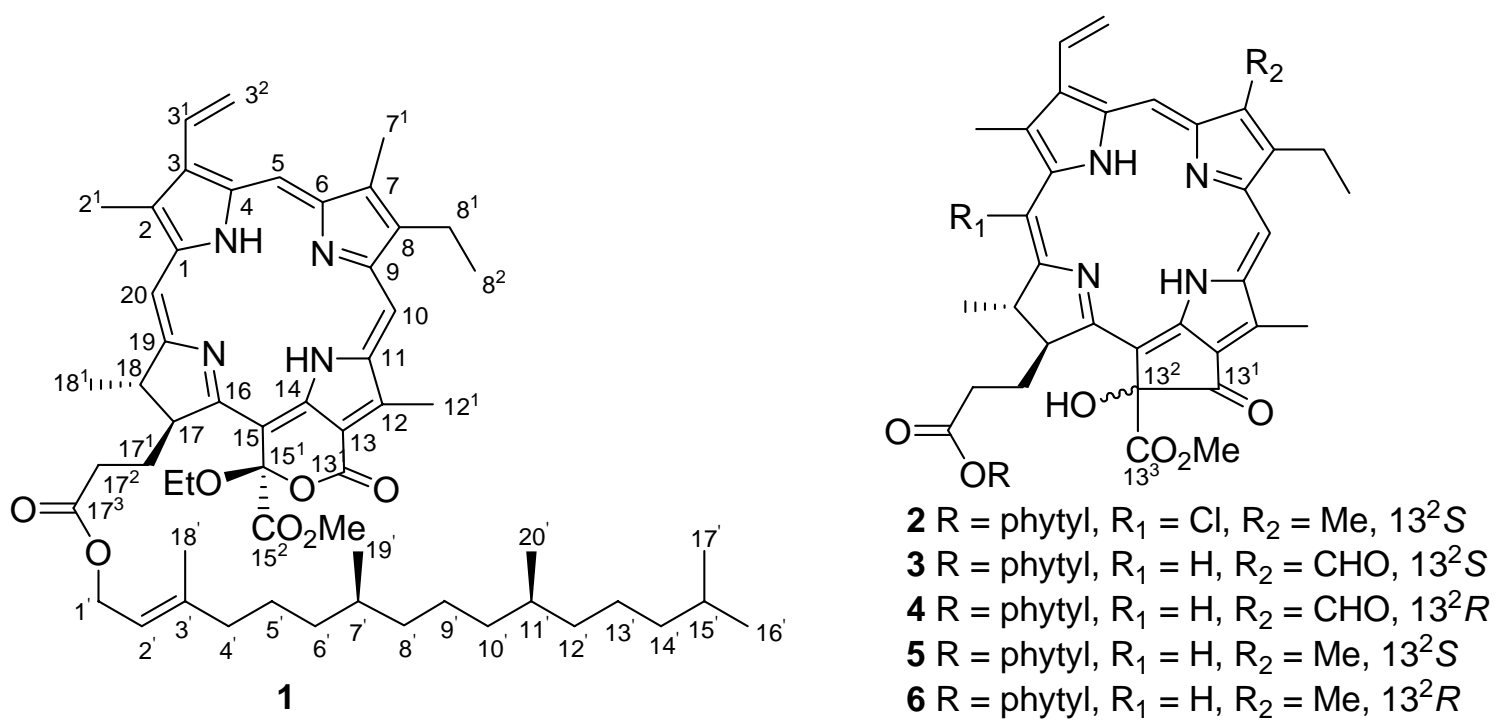

Porphyrinolactone (1) was isolated as a brown-red amorphous solid, and its molecular formula was determined as $\mathrm{C}_{57} \mathrm{H}_{78} \mathrm{~N}_{4} \mathrm{O}_{7}$ by HRFABMS ( $\mathrm{m} / \mathrm{z}$ 931.5943, calcd. 931.5958), indicating 21 degrees of unsaturation. The IR absorptions at 3343, 1741, and $1603 \mathrm{~cm}^{-1}$ and the UV bands at 224, 302, 400, 499, 529, 612, and $668 \mathrm{~nm}$ were characteristic of a porphyrin-based ester. In the ${ }^{1} \mathrm{H}-\mathrm{NMR}$ spectrum, three 
unusual downfield-shifted olefinic protons at $\delta_{\mathrm{H}} 9.55(\mathrm{~s}), 9.78(\mathrm{~s})$, and $8.75(\mathrm{~s})$ were characteristic of H-5, H-10, and H-20 of porphyrin nucleus. The ${ }^{1} \mathrm{H}-\mathrm{NMR}$ signals observed at $\delta_{\mathrm{H}} 3.47\left(\mathrm{~s}, \mathrm{H}_{3}-2^{1}\right), 3.29$ (s, $\mathrm{H}_{3}-7^{1}$ ), and 3.94 (s, $\mathrm{H}_{3}-12^{1}$ ) for three olefinic methyl groups, and the proton resonances at $\delta_{\mathrm{H}} 8.02$ (dd, $J=11.5,17.5 \mathrm{~Hz}, \mathrm{H}-3^{1}$ ), 6.36 (dd, $J=2.3,17.5 \mathrm{~Hz}, \mathrm{H}-3^{2} \mathrm{a}$ ), and 6.20 (dd, $J=2.3,11.5 \mathrm{~Hz}, \mathrm{H}-3^{2} \mathrm{~b}$ ) for a mono-substituted vinyl group corresponded to those of phaeophytin $\mathrm{A}$ and its derivatives $[7,10]$. The ${ }^{1} \mathrm{H}$ - and ${ }^{13} \mathrm{C}$-NMR data of $\mathbf{1}$ closely resembled those of $13^{2}$-hydroxyphaeophytin A, expect for ring E, where 1 present a conjugated carbonyl carbon at $\delta_{\mathrm{C}} 161.4$ (s) and a quaternary carbon at $\delta_{\mathrm{C}} 106.3$ (s, $\mathrm{C}-15^{1}$ ) instead of the resonances at $\delta_{\mathrm{C}} 192.0$ (s) and 89.1 (s) for the corresponding carbons of the former. The NMR data, in association with the degrees of unsaturation, allowed us to establish a conjugated $\delta$-lactone structure, that was supposed to be formed between $\mathrm{C}-13^{1}-\mathrm{C}-13^{2}$ bond at ring $\mathrm{E}$ of $13^{2}$-hydroxyphaeophytin A via oxidation and ring cleavage. An additional ethoxy group was identified from the ${ }^{1} \mathrm{H}$ resonances at $\delta_{\mathrm{H}} 4.36$ (q, $J=7.0 \mathrm{~Hz}, \mathrm{H}_{2}-1$ ”) and $1.60\left(\mathrm{t}, J=7.0 \mathrm{~Hz}, \mathrm{H}_{3}-2\right.$ ”) and the respective carbons at $\delta_{\mathrm{C}} 62.4(\mathrm{t})$ and $15.6(\mathrm{q})$. This ethoxy group was deduced to be positioned at $\mathrm{C}-13^{2}$ based on the HMBC correlation between $\mathrm{H}_{2}-1$ ” and C-15 ${ }^{1}$. In addition, a phytyl moiety was confirmed by extensive 2D NMR (DQFCOSY, HMQC, and HMBC) spectroscopic data analyses, and this unit was connected to the carbonyl carbon $\mathrm{C}-17^{3}$ to form an ester according to the HMBC correlation. The configuration of $\mathrm{C}-15^{1}$ was determined to be $R$, based on the downfield shift of $\mathrm{H}-17\left(\delta_{\mathrm{H}} 4.82\right)$, in contrast with $\delta_{\mathrm{H}} 4.16 \mathrm{ppm}$ for the $S$ configuration, as concluded by Nakatani [9]. The stereochemistry of ring D was assumed to be $17 S$ and $18 S$ as in "normal" phaeophytins, which was supported by $90^{\circ}$ dihedral angle between vicinal protons $\mathrm{H}-17\left(\delta_{\mathrm{H}} 4.82, \mathrm{~d}\right)$ and $\mathrm{H}-18\left(\delta_{\mathrm{H}} 4.45, \mathrm{q}\right)$ for trans orientation, and the NOE correlations between $\mathrm{H}-17$ and $\mathrm{H}_{3}-18^{1}\left(\delta_{\mathrm{H}} 1.62, \mathrm{~d}\right)$ and the methoxy protons at $\delta_{\mathrm{H}} 3.60$ (s). The $\delta$-lactone of $\mathbf{1}$ was supposedly be generated from phaeophytin $\mathrm{A}$ as a precursor via an allomerization pathway (Scheme 1) [10]. The ethoxy group was assumed to be introduced as an artifact during the EtOH extraction process.

Scheme 1. Hypothetical biotransformation from phaeophytin A to $\mathbf{1 .}$
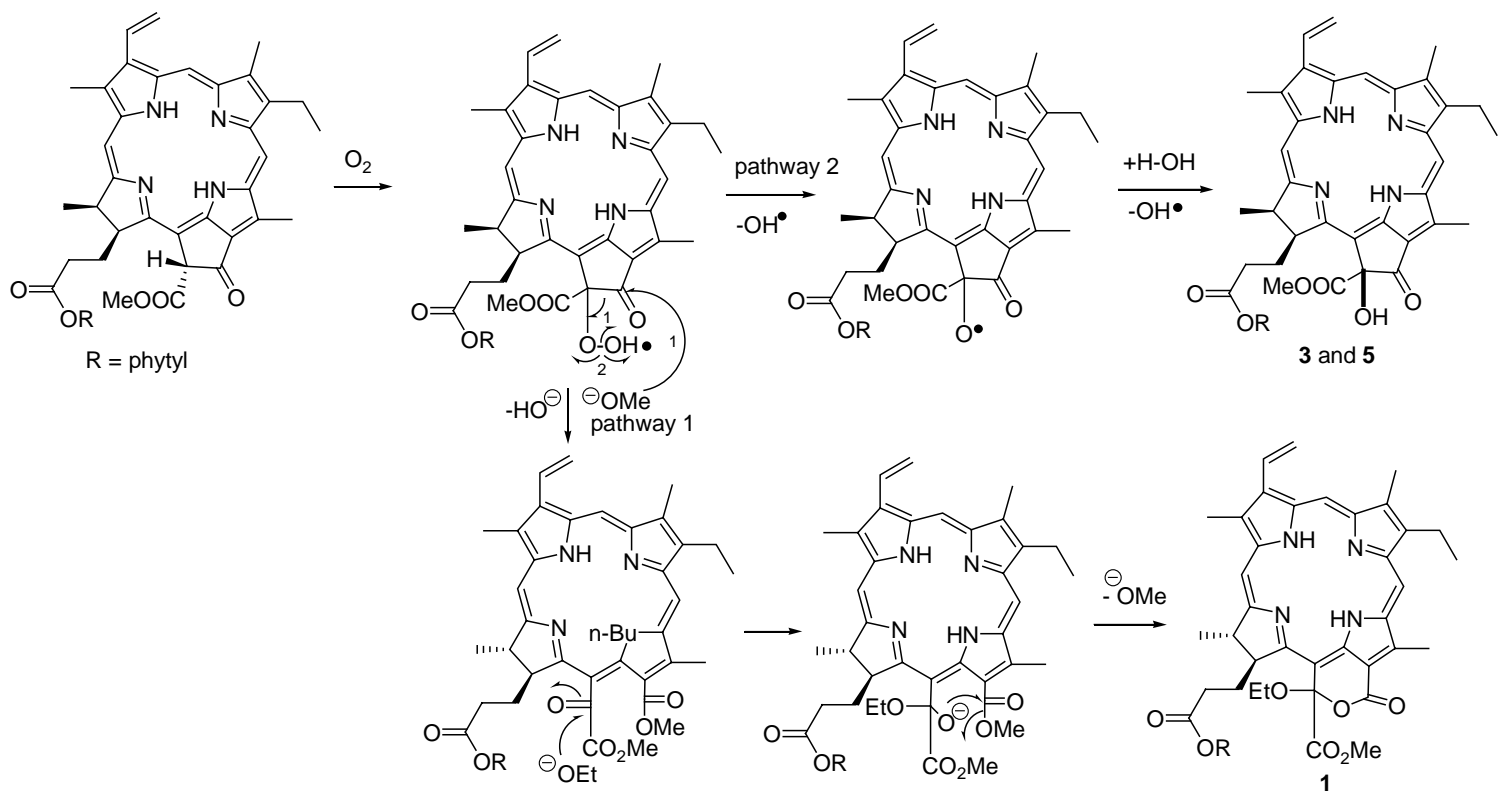
The remaining known compounds were identical to sterols $\beta$-sitosterol [11], $\beta$-sitosterol-7-one [11], ergosta-5,24(28)-dien-3 $\beta$-ol [11], ergosta-5,24(28)-dien-3 $\beta$-ol-7-one [11], fucosterol [12], saringosterol [12], 24(28)epoxystigmast-5-dien-3 $\beta$-ol [12], and 24-hydroperoxy-28-vinyl-cholesterol [12], while the six cycloartanes were consistent with 24-hydroperoxy-cycloart-25-en-3 $\beta$-ol [13-14], cycloart-25-en-3 $\beta$, 24-diol [15], 25-hydroperoxycycloart-23-en-3 $\beta$-ol [13], cycloart-23-en-3 $\beta$, 25-diol [13-14], cycloart-23,25-dien-3 $\beta$-ol [16], and cycloart-24-en-3 $\beta$-ol [13-14]. These compounds were identified by directly comparison of their spectroscopic data with literature values. The cycloartane-type derivatives were obtained for the first time from marine algae.

Previous reports had indicated that pheophorbide possessed the capability to interfere with NF-кB activation [17]. In this study, we tested compounds 1-6 for their in vitro inhibitory effects against NF- $\kappa$ B translocation activated by TNF- $\alpha$ (tumor necrosis factor alpha) under condition so as to avoid illumination by HCS. Results are shown in Figure 2.

Figure 2. Inhibitory effect of 1-6 on TNF- $\alpha$ - induced NF- $\kappa$ B activation in HeLa cells. A. Percentage of inhibitory rate of NF- $\kappa$ B activation induced by $50 \mathrm{ng} / \mathrm{ml}$ of TNF- $\alpha$ in HeLa cells after treatment with of 1-6 (50 $\mu \mathrm{M}$ for each). MG132 (5 $\mu \mathrm{M})$ was used as a positive control. B. Composite imagines of HeLa cells treated with DMSO (0.1\%) (a), TNF- $\alpha$ (50 ng/ml) (b), TNF- $\alpha(50 \mathrm{ng} / \mathrm{ml})+4(10 \mu \mathrm{M})(\mathrm{c}) ; \mathrm{TNF}-\alpha(50 \mathrm{ng} / \mathrm{ml})+4(50 \mu \mathrm{M})(\mathrm{d})$.

A

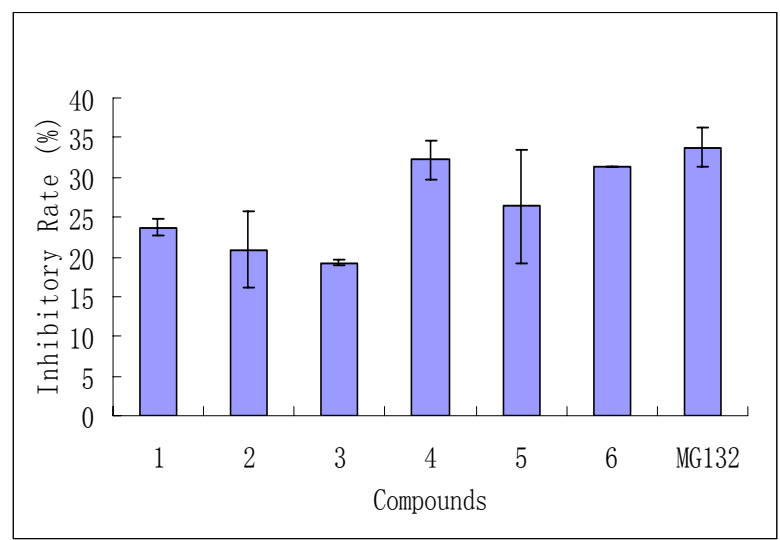

B

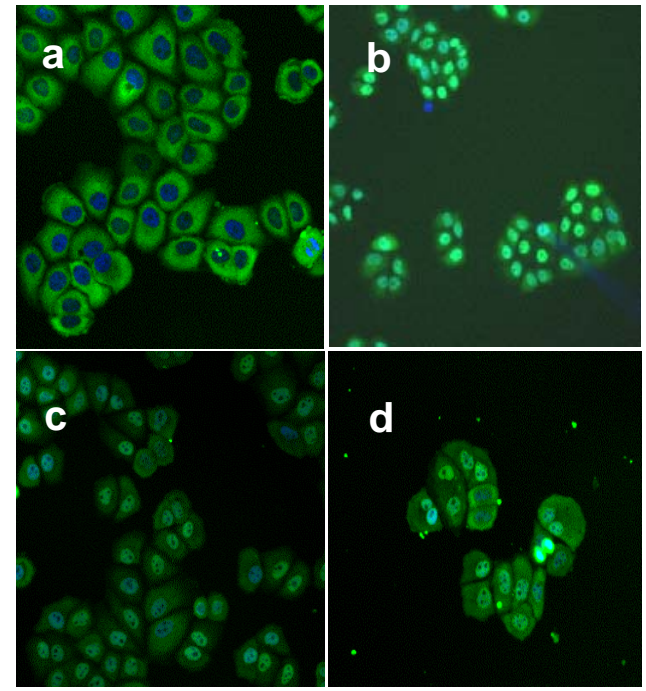




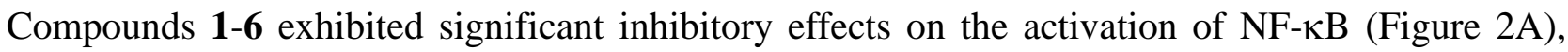
while 4 and $\mathbf{6}$ showed potential suppression with inhibition rates that were comparable with the value of MG132 (a positive control for NF- $\mathrm{B}$ translocation). In parallel, the morphological changes of $\mathrm{NF}-\kappa \mathrm{B}$ translocation indicated by immunofluorescence staining (Figure 2B) showed an inhibitory effect of 4 on TNF- $\alpha$-induced NF- $\kappa$ B translocation in a dose-dependent manner. In cells treated with solvent control (Figure 2Ba), most of the fluorescence staining for NF- $\kappa \mathrm{B}$ are in the cytoplasm and rare $\mathrm{NF}-\kappa \mathrm{B}$ staining in nuclei area. When stimulating the cells with the TNF- $\alpha$ alone (Figure $2 \mathrm{Bb}$ ), NF- $\kappa \mathrm{B}$ staining significantly increased in nuclei area, suggesting that NF- $\kappa \mathrm{B}$ translocated from cytoplasm into the nucleus. However, HeLa cells were treated with 4 by using the dosages of 10 and $50 \mu \mathrm{M}$ (Figure $2 \mathrm{Bc}, \mathrm{d}), \mathrm{NF}-\kappa \mathrm{B}$ translocation induced by TNF- $\alpha$ was inhibited dose-dependently. This result provided a new evidence to support the suggestion that the cytotoxic effect of chlorophyll derivatives can occur through mechanisms other than phytodynamic action [18].In order to understand the molecular mechanism of 1-6 on the inhibitory effect of NF- $\kappa \mathrm{B}$ translocation, we examined their effect on proteasome ChT-L activity (Figure 3) by using an in vitro enzymatic activity assay. Compounds 2 and 4 showed a remarkable inhibitory effect on proteasome ChT-L activity (inhibitory rates among 70-73.5\%), while 3 exhibited moderate activity. The primary bioassay result implied that paeophytin b type (3-4) showed stronger inhibition toward to proteasome ChT-L than that of paeophytin a type (5-6), indicating the aldehyde functionality at C-7 plays a key role in the inhibitory effect. Comparison of inhibitory activity between epimers $\mathbf{3}$ and $\mathbf{4}$, and between $\mathbf{5}$ and $\mathbf{6}$, revealed that a $13^{2}-S$ configuration gave stronger inhibition than that of $13^{2}-R$. The 20-chlorinated $13^{2}-S$ paeophytin A (2) increased the inhibitory effect by comparison with the data of $13^{2}-S$ paeophytin A. This was the first time phaeophytins were reported to inhibit proteasome ChT-L activity, but the present data could not provide evidence to explain the relationship of inhibitory effects between NF- $\kappa$ B and ChT-L, although the proteasome inhibition is related to NF- $\kappa \mathrm{B}$ inhibition.

Figure 3. Effect of 1-6 on $20 S$ proteasome ChT-L activity. $20 S$ proteasome was incubated with compounds 1-6 (50 $\mu \mathrm{M}$ of each) and fluorogenic peptide (100 $\mu \mathrm{M})$ in 100 $\mu \mathrm{L}$ of $20 \mathrm{mM}$ Tris- $\mathrm{HCl}$ ( $\mathrm{pH} 7.8$ ), at $37^{\circ} \mathrm{C}$ for 1 hour. The proteasome ChT-L activity was assayed after addition of specific substrate. MG132 $(1.0 \mu \mathrm{M})$ was used as a positive control. Data were measured by means of \pm SD from three independent experiments.

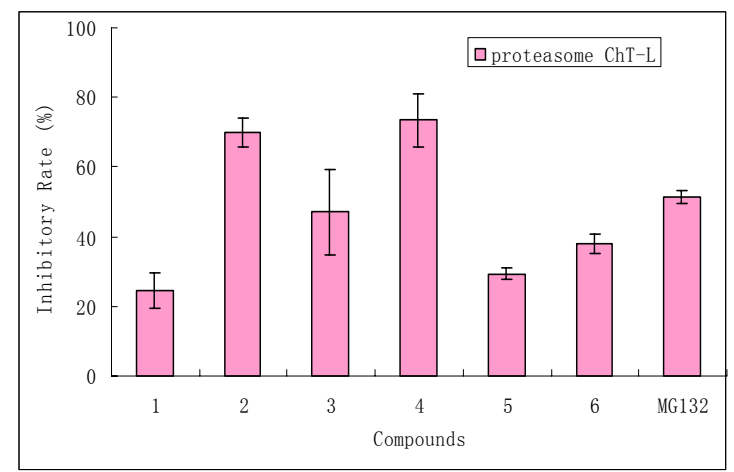

The ubiquitin-proteasome pathway (UPP) is a major nonlysosomal system responsible for intracellular protein degradation in eukaryotic cells [19]. The key proteins modulated by the proteasome are those involving in the affection of inflammatory processes, cell cycle regulation, and gene expression. Proteasome inhibition is a potential treatment option for cancer and inflammatory 
conditions [20-21], NF- $\kappa \mathrm{B}$ is a crucial transcription factor mediated by immune responses and cellular

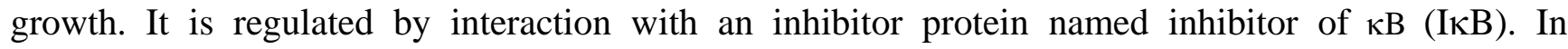
quiescent cells, NF- $\kappa B$ presents in the cytoplasm and binds to its inhibitor $\mathrm{I} \kappa \mathrm{B}$. When a cell is stimulated by stress, growth factors, radiation, etc; $\mathrm{I} \kappa \mathrm{B}$ could be phosphorylated and degraded by the UPP, freeing NF- $\kappa \mathrm{B}$ to translocate to the nucleus where it activates transcription. Proteasome inhibition could stabilize I $\kappa \mathrm{B}-\mathrm{NF}-\kappa \mathrm{B}$ complex making the NF- $\kappa \mathrm{B}$ inactive [22]. Thereby, the NF- $\kappa \mathrm{B}$ signaling pathway is an important target of proteasome inhibitors for the prevention and treatment drugs against cancer and inflammation. Moreover, NF- $\kappa \mathrm{B}$ constitutive activity is one of the most important reasons that leading the MRD (multidrug resistance) of tumor cells [23]. Thus, the inhibitor of proteasome and NF- $\mathrm{BB}$ activities will be a promising candidate for new anti-inflammation or anticancer drug, especially for MRD tumour cells.

\section{Experimental}

\section{General}

IR spectra were recorded on a Perkin-Elmer Nicol FT-50X spectrometer. UV spectra were measured on a UV-VIS spectrophotometer 756MC. ${ }^{1} \mathrm{H}$-, ${ }^{13} \mathrm{C}-\mathrm{NMR}$ and $2 \mathrm{D}$ NMR spectra were recorded on Bruker Avance-500 FT NMR or Varian INOVA $500 \mathrm{MHz}$ spectrometers, and chemical shifts were referenced to the solvent $\mathrm{CDCl}_{3}$ as internal standard. FABMS spectra were measured on a Bruker FTICR APEXII mass spectrometer while HRFABMS were measured on a Bruker Daltonics. Inc. APEX-II FTPICRMS. Column chromatography was carried with silica gel (200-300 mesh), and $\mathrm{HF}_{254}$ silica gel for TLC was obtained from Qingdao Marine Chemistry Co. Ltd., Qingdao, China. Sephadex LH-20 (18-110 $\mu \mathrm{m})$ was provided by Pharmacia Co.

\section{Algal material}

The green alga Clodophora fascicularis was collected in shallow seawater along the coastline of Qingdao, China, in November 2003. The algal species was identified by Professor Baoren Lu from the Institute of Oceanology, Chinese Academy of Science (CAS). A voucher specimen (no. 20031101) is deposited at the Institute of Oceanology Chemistry Department of Marine Algae.

\section{Extraction and isolation}

Air-dried C. fascicularis (6.5 kg) was percolated with EtOH under room temperature for one week. The EtOH extract was concentrated in vacuo to afford a dark green residue (308.0 g). This residue was suspended in water and then partitioned successively with petroleum ether, EtOAc, and $n$-BuOH. The petroleum ether fraction (40.0 g) was subjected to silica gel column chromatography eluting with a 100:1 to 1:1 gradient of petroleum ether-EtOAc. The collection was monitored by TLC to obtain 20 fractions F1-F20. F10 (80 mg) was subjected to Sephadex LH-20 column chromatography with an 4:1 $\mathrm{MeOH}-\mathrm{H}_{2} \mathrm{O}$ eluant to afford 1 (6.0 mg), 2 (6.0 mg), and saringosterol (11.0 mg). F13 (50.0 mg) was separated by Sephadex LH-20 column chromatography eluting with (4:1) MeOH- $\mathrm{H}_{2} \mathrm{O}$ to yield 5 (20.0 mg), 6 (15.0 mg), 24-hydroperoxy-28-vinylcholesterol (21.0 mg) and 24-hydroperoxycycloart-25- 
en-3 $\beta$-ol (7.0 mg), respectively. F14 (200 mg) was treated in the same manner as F13 on a Sephadex LH-20 column chromatography to give a main fraction which was further purified on a silica gel column with 8:1 petroleum ether-acetone as eluant to afford 3 (4.0 mg), 4 (4.5 mg), $\beta$-sitosterol (31 $\mathrm{mg}$ ), $\beta$-sitosterol-7-one (5.6 mg), and 25-hydroperoxycycloart-23-en-3 $\beta$-ol (15.0 mg). F8 (70 mg) was further chromatographed on a silica gel column and eluted with 20:1 petroleum ether-acetone to afford fucosterol (30.0 mg), 24(28)epoxystigmast-5-dien-3 $\beta$-ol (15.0 mg) and cycloart-25-en-3 $\beta$, 24-diol (5.6 $\mathrm{mg})$. F9 (180 mg) was chromatographed on a silica gel column in the same manner as F-8 to afford ergosta-5,24(28)-dien-3 $\beta$-ol-7-one (11.0 mg). F17 (150.0 mg) was repeatedly separated by silica gel column chromatography eluting with $4: 1$ petroleum ether-acetone to yield ergosta-5,24(28)-dien-3 $\beta$-ol (9.0 mg), cycloart-23-en-3 $\beta, 25$-diol (15.0 mg), cycloart-23,25-dien-3 $\beta$-ol (2.5 mg), and cycloart-24en-3 $\beta$-ol (4.0 mg).

\section{Chemical and physical data of porphyrinolactone (1)}

Brown-red amorphous powder; IR (KBr) $v_{\max }$ 3343, 2955, 2925, 2855, 1741, 1603, 1460, 1378, 1250, 1162, $1086 \mathrm{~cm}^{-1}$; UV (MeOH) $\lambda_{\max }$ 224, 302, 400, 499, 529, 612, $668 \mathrm{~nm}$; FABMS m/z 931 $[\mathrm{M}+1]^{+}$; HRFABMS m/z 931.5958 (calcd for $\mathrm{C}_{57} \mathrm{H}_{79} \mathrm{~N}_{4} \mathrm{O}_{7}$, 931.5943); ${ }^{1} \mathrm{H}$ - and ${ }^{13} \mathrm{C}-\mathrm{NMR}$ data, see Table 1.

\section{Chemical and physical data of 20-chloro-(132-S)-hydroxyphaeophytin A (2)}

Brown-green amorphous powder; IR (KBr) $v_{\max } 3367,2955,2923,2852,1740,1715,1608,1461$, 1223, 1159, $1107 \mathrm{~cm}^{-1}$; UV (MeOH) $\lambda_{\max }$ 218, 300, 412, 513, 544, 617, 676 nm; FABMS m/z 921 [M $+1]^{+}$; HRFABMS $\mathrm{m} / \mathrm{z} 943.5160$ (calcd for $\mathrm{C}_{55} \mathrm{H}_{73} \mathrm{ClN}_{4} \mathrm{O}_{6} \mathrm{Na}, 943.5110$ ). ${ }^{1} \mathrm{H}$ - and ${ }^{13} \mathrm{C}-\mathrm{NMR}$ data, see Table 1.

Table 1. ${ }^{1} \mathrm{H}$ - and ${ }^{13} \mathrm{C}-\mathrm{NMR}$ data of compounds 1 and 2 (500/125 MHz, respectively, in $\mathrm{CDCl}_{3} ; \delta$ in ppm, $J$ in $\mathrm{Hz}$ ).

\begin{tabular}{lllll}
\hline \multirow{2}{*}{ No. } & Compound 1 & H & \multicolumn{2}{l}{ Compound 2 } \\
& $\mathbf{C}$ & & $\mathbf{H}$ \\
\hline 1 & $141.3 \mathrm{~s}$ & & $137.9 \mathrm{~s}$ & \\
2 & $131.6 \mathrm{~s}$ & & $132.2 \mathrm{~s}$ & \\
$2^{1}$ & $12.1 \mathrm{q}$ & $3.47 \mathrm{~s}$ & $17.1 \mathrm{q}$ & $3.64 \mathrm{~s}$ \\
3 & $136.3 \mathrm{~s}$ & & $139.9 \mathrm{~s}$ & \\
$3^{1}$ & $129.0 \mathrm{~d}$ & $8.02 \mathrm{dd} 11.5,17.5$ & $129.5 \mathrm{~d}$ & $8.00 \mathrm{dd} 11.5,17.5$ \\
$3^{2}$ & $122.7 \mathrm{t}$ & $6.20 \mathrm{dd} 2.3,17.5$ & $125.0 \mathrm{t}$ & $6.22 \mathrm{dd} 2.3,17.5$ \\
& & $6.36 \mathrm{dd} 2.3,11.5$ & & $6.34 \mathrm{dd} 2.3,11.5$ \\
4 & $135.1 \mathrm{~s}$ & & $133.7 \mathrm{~s}$ & \\
5 & $99.5 \mathrm{~s}$ & $9.55 \mathrm{~s}$ & $99.9 \mathrm{~d}$ & $9.72 \mathrm{~s}$ \\
6 & $156.0 \mathrm{~s}$ & & $154.1 \mathrm{~s}$ & \\
7 & $136.1 \mathrm{~s}$ & & $137.3 \mathrm{~s}$ & \\
$7^{1}$ & $11.3 \mathrm{q}$ & $3.29 \mathrm{~s}$ & $11.3 \mathrm{q}$ & $3.32 \mathrm{~s}$ \\
8 & $145.5 \mathrm{~s}$ & & $144.9 \mathrm{~s}$ & \\
$8^{1}$ & $19.6 \mathrm{t}$ & $3.76 \mathrm{q} 7.0$ & $19.5 \mathrm{t}$ & $3.77 \mathrm{q} \mathrm{7.0}$ \\
\hline
\end{tabular}


Table 1. Cont.

\begin{tabular}{|c|c|c|c|c|}
\hline \multirow{2}{*}{ No. } & \multicolumn{2}{|c|}{ Compound 1} & \multicolumn{2}{|c|}{ Compound 2} \\
\hline & C & $\mathbf{H}$ & C & $\mathbf{H}$ \\
\hline $8^{2}$ & $17.6 \mathrm{q}$ & 1.73 t 7.0 & $17.4 \mathrm{q}$ & 1.74 t 7.0 \\
\hline 9 & $150.0 \mathrm{~s}$ & & $152.1 \mathrm{~s}$ & \\
\hline 10 & $104.1 \mathrm{~d}$ & $9.78 \mathrm{~s}$ & $103.8 \mathrm{~d}$ & $9.72 \mathrm{~s}$ \\
\hline 11 & $139.1 \mathrm{~s}$ & & $139.5 \mathrm{~s}$ & \\
\hline 12 & $131.4 \mathrm{~s}$ & & $131.0 \mathrm{~s}$ & \\
\hline $12^{1}$ & $12.5 \mathrm{q}$ & $3.94 \mathrm{~s}$ & $12.4 \mathrm{q}$ & $3.78 \mathrm{~s}$ \\
\hline 13 & $112.2 \mathrm{~s}$ & & $128.1 \mathrm{~s}$ & \\
\hline $13^{1}$ & $161.4 \mathrm{~s}$ & & $191.8 \mathrm{~s}$ & \\
\hline $13^{2}$ & & & $89.3 \mathrm{~s}$ & \\
\hline $13^{3}$ & & & $172.8 \mathrm{~s}$ & \\
\hline 14 & $136.3 \mathrm{~s}$ & & $149.0 \mathrm{~s}$ & \\
\hline 15 & $101.5 \mathrm{~s}$ & & $108.3 \mathrm{~s}$ & \\
\hline $15^{1}$ & $106.3 \mathrm{~s}$ & & & \\
\hline $15^{2}$ & $169.1 \mathrm{~s}$ & & & \\
\hline 16 & $167.8 \mathrm{~s}$ & & $162.9 \mathrm{~s}$ & \\
\hline 17 & $53.9 \mathrm{~d}$ & $4.82 \mathrm{~d} 7.0$ & $51.8 \mathrm{~d}$ & $4.20 \mathrm{~d} 7.5$ \\
\hline $17^{1}$ & $32.2 \mathrm{t}$ & $1.90 \mathrm{~m} ; 2.62 \mathrm{~m}$ & $31.6 \mathrm{t}$ & $1.92 \mathrm{~m} ; 2.60 \mathrm{~m}$ \\
\hline $17^{2}$ & $32.5 \mathrm{t}$ & $2.21 \mathrm{~m} ; 2.48 \mathrm{~m}$ & $30.8 \mathrm{t}$ & $2.20 \mathrm{~m} ; 2.46 \mathrm{~m}$ \\
\hline $17^{3}$ & $173.2 \mathrm{~s}$ & & $173.5 \mathrm{~s}$ & \\
\hline 18 & $50.0 \mathrm{~d}$ & 4.45 q 7.0 & $50.0 \mathrm{~d}$ & 4.89 q 7.0 \\
\hline $18^{1}$ & $22.6 \mathrm{q}$ & $1.62 \mathrm{~d} 7.0$ & $19.7 \mathrm{q}$ & $1.50 \mathrm{~d} 7.0$ \\
\hline 19 & $171.8 \mathrm{~s}$ & & $171.2 \mathrm{~s}$ & \\
\hline 20 & $94.0 \mathrm{~d}$ & $8.75 \mathrm{~s}$ & $106.4 \mathrm{~s}$ & \\
\hline $1^{\prime}$ & $61.3 \mathrm{t}$ & $4.43 \mathrm{~d} 7.0$ & $61.6 \mathrm{t}$ & 4.62 d 7.0 \\
\hline $2^{\prime}$ & $117.8 \mathrm{~d}$ & 5.16 t 7.0 & $117.8 \mathrm{~d}$ & 5.26 t 7.0 \\
\hline 3 & $142.6 \mathrm{~s}$ & & $142.8 \mathrm{~s}$ & \\
\hline $4^{\prime}$ & $39.8 \mathrm{t}$ & $1.90 \mathrm{~m}$ & $39.8 \mathrm{t}$ & $1.88 \mathrm{~m}$ \\
\hline 5 ' & $24.8 \mathrm{t}$ & $1.60 \mathrm{~m} ; 1.72 \mathrm{~m}$ & $24.8 \mathrm{t}$ & $1.62 \mathrm{~m} ; 1.70 \mathrm{~m}$ \\
\hline $6{ }^{\prime}$ & $36.6 \mathrm{t}$ & $1.00 \mathrm{~m} ; 1.20 \mathrm{~m}$ & $36.6 \mathrm{t}$ & $1.00 \mathrm{~m} ; 1.20 \mathrm{~m}$ \\
\hline 7' & $32.6 \mathrm{~d}$ & $1.30 \mathrm{~m}$ & $32.6 \mathrm{~d}$ & $1.32 \mathrm{~m}$ \\
\hline $8^{\prime}$ & $37.4 \mathrm{t}$ & $1.03 \mathrm{~m} ; 1.26 \mathrm{~m}$ & $37.3 \mathrm{t}$ & $1.03 \mathrm{~m} ; 1.26 \mathrm{~m}$ \\
\hline 9' & 24.8 & $1.28 \mathrm{~m}$ & $25.0 \mathrm{t}$ & $1.28 \mathrm{~m}$ \\
\hline $10^{\prime}$ & $36.7 \mathrm{t}$ & $1.26 \mathrm{~m}$ & $37.3 \mathrm{t}$ & $1.26 \mathrm{~m}$ \\
\hline $11^{\prime}$ & $32.6 \mathrm{~d}$ & $1.30 \mathrm{~m}$ & $32.8 \mathrm{~d}$ & $1.30 \mathrm{~m} ; 1.26 \mathrm{~m}$ \\
\hline $12^{\prime}$ & $37.3 \mathrm{t}$ & $1.03 \mathrm{~m} ; 1.26 \mathrm{~m}$ & $37.2 \mathrm{t}$ & $1.03 \mathrm{~m} ; 1.26 \mathrm{~m}$ \\
\hline 13' & $24.4 \mathrm{t}$ & $1.60 \mathrm{~m}$ & $24.4 \mathrm{t}$ & $1.60 \mathrm{~m}$ \\
\hline $14^{\prime}$ & $39.4 \mathrm{t}$ & $1.15 \mathrm{~m}$ & $39.3 \mathrm{t}$ & $1.15 \mathrm{~m}$ \\
\hline $15^{\prime}$ & $28.0 \mathrm{~d}$ & $1.51 \mathrm{~m}$ & $27.9 \mathrm{~d}$ & $1.50 \mathrm{~m}$ \\
\hline $16^{\prime}$ & $22.7 \mathrm{q}$ & 0.87 d 6.8 & $22.7 \mathrm{q}$ & 0.87 d 6.8 \\
\hline 17' & $22.6 \mathrm{q}$ & 0.87 d 6.8 & $22.6 \mathrm{q}$ & 0.87 d 6.8 \\
\hline $18^{\prime}$ & $16.2 \mathrm{q}$ & $1.56 \mathrm{~s}$ & $16.3 \mathrm{q}$ & $1.66 \mathrm{~s}$ \\
\hline $19^{\prime}$ & $19.6 \mathrm{q}$ & 0.76 d 6.5 & $19.6 \mathrm{q}$ & 0.84 d 6.5 \\
\hline $20{ }^{\prime}$ & $19.7 \mathrm{q}$ & $0.82 \mathrm{~d} 6.5$ & $19.7 \mathrm{q}$ & 0.83 d 6.5 \\
\hline
\end{tabular}




\section{Detection of NF-kB activity}

HCS (high-content screening) was used to detect data on multiple parameters in single cells as well as in populations of cells [24], aiming to measure the inhibitory effects of compounds on TNF- $\alpha$-induced NF- $\kappa$ B activation, i.e. nuclear translocation of NF- $\kappa$ B. The HeLa cells were seeded in 96-well microplates and incubated in $24 \mathrm{~h}$ for fluorescence detection (Costar 3603) at $5 \times 10^{4}$ cells/well (100 $\mu \mathrm{L} /$ well). Exponentially growing cells were exposed to $50 \mu \mathrm{M}$ of compounds 1-6 or PBS (untreated control) and $N$-carbobenzoxyl-Leu-Leu-leucinal (MG132, $5 \mu \mathrm{M}$, positive control), respectively, for $60 \mathrm{~min}$. Afterwards, TNF- $\alpha$ (50 ng/mL, R\&D Co.) was added and samples were kept in additional $30 \mathrm{~min}$. The procedure including cell fixation, permeabilization and staining for imaging analysis was prepared according to the manufacturer's instructions for the NF- $\kappa$ B activation kit (HitKit K01-0001-01, Cellomics). The Cytoplasm to Nucleus Translocation BioApplication (software) is capable of measuring the activation and/or translocation of one target at a time at the single cell level. It analyzes images obtained from the HCS Readers (KineticScan ${ }^{\mathrm{TM}}$ Reader, Cellomics) and measures differences and ratios of fluorescence intensities between two sub-cellular compartments: the cytoplasm and the nucleus. In Channel 1, nuclei (DNA) stained with the fluorescent dye Hoechst 33342 defines the nuclear region called Circ. In Channel 2 (the target channel), NF- $\kappa$ B is stained with the second antibody conjugated with the fluorophore Alexa Fluor 488 [25]. An annular region called Ring is defined in the cytoplasm beyond the nuclear (i.e., Circ) region. The size of the Circ and Ring masks in the target channel can be adjusted appropriately so that the Circ and Ring masks approximate a measure of the nuclear and cytoplasm concentration of the target respectively. The output feature MEAN_CircRingAvgIntenDiffCh2 is an indicator of activation/translocation of macromolecules between the nucleus and the cytoplasm in the target channel at the cell level. This feature reports the difference in average pixel intensity between the Circ and Ring mask regions, so it is selected to calculate the inhibitory rate of the compounds on NF- $\kappa \mathrm{B}$ activity, and the rate is expressed as a percentage of negative control. All samples were performed at least duplicate and run in triplicate.

\section{Detection for proteasome ChT-L activity}

The enzymatic activity of the proteasome was assayed using fluorogenic peptides Suc-Leu-leu-Val-Tyr-AMC [Suc (succinyl) and AMC (7-amido-4-methylcoumarin) were obtained from SIGMA] for chymotryptic-like (ChT-L) activity [26]. 20S proteasome (1.0 $\mu \mathrm{g})$ was purified from human erythrocytes and then incubated with compounds 1-6 (50 $\mu \mathrm{M}$ of each) and fluorogenic peptides $(100 \mu \mathrm{M})$ in $20 \mathrm{mM}$ Tris-HCl $(100 \mu \mathrm{L}, \mathrm{pH} 7.8)$ at $37^{\circ} \mathrm{C}$ for $1 \mathrm{~h}$, respectively. The fluorescence of released 7-amido-4-methylcoumarin (AMC) was measured by a spectrofluorimeter (Fluostar OPTIMA, BMG Germany) at excitation/emission wavelengths of 380/440 nm. MG132 (1.0 $\mu \mathrm{M})$, a known inhibitor of proteasome ChT-L activity and $0.1 \%$ DMSO were used as positive and solvent control, respectively. By comparison with the fluorescence of solvent control, an inhibition rate for each compound was calculated. All samples were prepared at least in duplicate and run in triplicate. The bioassays mentioned above were performed under the conditions to avoid illumination. 


\section{Acknowledgements}

This study was supported by grants from NSFC (No. 30672607), the National Hi-Tech Projects (2006AA09Z446, 2006DFA31100), China Uni-PhD Base Project (20060001149) and the International Cooperation Projects of BMBF-CNCBD. We would like to thank Prof. P. Lin of Xia Men University for identification of the plant material and Professor Bao Ren Lu for the identification of the algae.

\section{References}

1. Duperon, R.; Thiersault, M.; Duperon, P. Occurrence of Steryl Glycosides and Acylated Steryl Glycosides in Some Marine Algae. Phytochemistry 1983, 22, 535-538.

2. Napoli, L.; Magno, S.; Mayol, L.; Novellino, E. Sterol Composition of Some Mediterranean Green Algae. Phytochemistry 1982, 21, 1993-1994.

3. Aknin, M.; Moellet-Nzaou, R.; Kornprobst, J. M.; Gaydou, E. M.; Samb, A.; Miralles, J. Sterol Composition of Twelve Chlorophyceae from the Senegalese Coast and Their Chemotaxonomic Significance. Phytochemistry 1992, 31, 4167-4169.

4. Elenkov, I.; Georgieva, T.; Dadjieva, P.; Dimitrova, S.; Dimitrova-Konaklieva, S.; Popov, S. Terpenoids and Sterols in Cladophora vagabunda. Phytochemistry 1995, 38, 457-459.

5. Koniyoshi, M.; Yamada, K.; Higa, T. Biologically Active Diphenyl Ether from the Green Alga Cladophora fascicularis. Experientia 1985, 41, 523-524.

6. Matsuo, A.; Ono, K.; Hamasaki, K.; Nozaki, H. Phaeophytins from A Cell Suspension Culture of the Liverwort Plagiochila ovalifolia. Phytochemistry 1996, 42, 427-430.

7. Buchanan, M. B.; Hashimoto, T.; Asakawa, Y. Phytyl Esters and Phaeophytins from the Hornwort Megaceros flagellaris. Phytochemistry 1996, 41, 1373-1376.

8. Senge, M.; Senger, H. Enzymic meso-Chlorination of Chlorphylls Using Chloroperoxidase. Biochim. Biophys. Acta 1989, 977, 177-186.

9. Nakatani, Y.; Ourisson, G.; Beck, J. P. Chemistry and Biochemistry of Chinese Drugs. VII Cytostatic Pheophytins from Silkworm Excreta and Derived Photocytotoxic Pheophorbides. Chem. Pharm. Bull. 1981, 29, 2261-2269.

10. Hynninen, P. H.; Hyvaerinen, K. Tracing the Allomerization Pathways of Chlorophylls by ${ }^{18}$ O-Labeling and Mass Spectrometry. J. Org. Chem. 2002, 67, 4055-4061.

11. Riccardis, F.; Luigi, M. Marine Sterols. Side-Chain-Oxygenated Sterolds, Possibly of Abiotic Origin, from the New Caledonian Sponge Stelodoryx chlorophylla. J. Nat. Prod. 1993, 56, 282-287.

12. Tang, H.; Yi, Y.; Yao, X.; Zhou, D.; Lu, T.; Jiang, Y. Studies on the Bioactive Steroid Constituents form Sargassum carpophllum. Chin. Pharm. J. 2002, 37, 262-265.

13. Cabrera, C. M.; Seldes, A. M. Hydroperoxycycloartanes from Tillandsia recurvata. J. Nat. Prod. 1995, 58, 1920-1924.

14. Cabrera, C. M.; Gallo, M.; Seldes, A. M. Cycloartane Derivatives from Tillandsia usneoides. J. Nat. Prod. 1996, 59, 343-347.

15. Greca, M. D.; Fiorentino, A.; Monaco, P.; Previtera, L. Cycloartane Triterpenes from Juncus effusus. Phytochemistry 1994, 35, 1017-1022. 
16. Li, G..; Wang, J.; Li, N.; Li, X. Cycloartane Triterpenoids from the Pericarp of Sphaerophysa salsula DC. J. Shengyang Pharma. Univ. 2003, 20, 252-254.

17. Heinrich, M.; Bork, P. M.; Schmitz, L.; Rimpler, H.; Frei, B.; Sticher, O. Pheaophorbide A from Solanum diflorum Interferes with NF-кB Activation. Planta Med. 2001, 67, 156-157.

18. Cheng, H.; Wang, H.; Ito, J.; Bastow, K. F.; Tachibana, Y.; Nakanishi, Y.; Xu, Z.; Luo, T.; Lee, K. Cytotoxic Pheophorbide-Related Compounds from Clerodendrum calamitosum and $C$. cyrtophyllum. J. Nat. Prod. 2001, 64, 915-919.

19. Kisselev, A.F.; Goldberg, A. L. Proteasome Inhibitors: from Research Tools to Drug Candidates. Chem. Biol. 2001, 8, 739-758.

20. Elliott, P. J.; Zollner, T._M.; Boehncke, W._H. Proteasome Inhibition: A New Anti-Inflammatory Strategy. J. Mol. Med. 2003, 81, 235-245.

21. Adams, J. Proteasome Inhibition: A Novel Approach to Cancer Therapy. Trends Mol. Med. 2002, 8S, 49-54.

22. Adams, J. The Proteasome: Structure, Function, and Role in the Cell. Cancer Treat Rev. Suppl 1 2003, 29, 3-9.

23. Um, J. H.; Kang, C. D.; Lee, B. G..; Kim, D. W.; Chung, B. S.; Kim, S. H. Increased and Correlated Nuclear Factor-Kappa B and Ku Autoantigen Activities are Associated with Development of Multidrug resistance. Oncogene 2001, 20, 6048-6056.

24. Giuliano, K. A.; Dunlay, D. R. L.; Gough, A.; Volosky, J. M.; Zock, J.; Pavlakis, G. N.; Taylor, D. L. High-Content Screening: A New Approach to Easing Key Bottlenecks in the Drug Discovery Process. J. Biomol. Screen. 1997, 2, 249-259.

25. Vakkila, J.; DeMarco, R. A.; Lotze, M. T. Imaging Analysis of STAT1 and NF-кB Translocation in Dendritic Cells at the Single Cell Level. J. Immuno. Methods 2004, 294, 123-134.

26. Bo, X.; Monsarrat, B.; Gairin, J. E.; Girbal-Neuhauser, E. Effect of Ajoene, A Natural Antitumor Small Molecule, on Human 20S Proteasome Activity in Vitro and in Human Leukemic HL-60 Cells. Fundam. Clin. Pharmacol. 2004, 18, 171-180.

Sample availability: Samples are available from the authors

(C) 2007 by MDPI (http://www.mdpi.org). Reproduction is permitted for noncommercial purposes. 